JIPS, Vol. 2 No. 2

Halaman: 134 - 146

Desember 2021

\title{
Peningkatan Kompetensi Pedagogik dalam Pembelajaran Daring Masa Pandemi Covid 19 Melalui Penerapan Supervisi Klinis pada Guru
}

\author{
ML. Dyah K. Anggraini \\ SDN Krapyak Semarang \\ ucikdyah@gmail.com
}

\begin{abstract}
Improving Pedagogic Competence in Online Learning During the Covid 19 Pandemic Period Through the Application of Clinical Supervision on Teachers at SD Negeri Krapyak, West Semarang District, Semarang City Semester 2 Year 2020/2021. This study aims to determine the effect of applying clinical supervision of online learning during the Covid 19 Pandemic on KRAPYAK State Elementary School teachers. This research was conducted for 4 Months of Semester II of the 2020/2021 academic year from the preparation of the proposal to the writing of the research report in December 2020 to April 2021. The subjects of the study were all class teachers of SD Negeri Krapyak. The method is a way to simplify the way research works and is a determining factor for the success of a study. The method used is school action research with two cycles of action. Each cycle consists of four stages, namely planning, taking action, observing, and reflecting. Analysis of the data used in this study using comparative descriptive analysis, namely by comparing the results of the initial test, the first cycle, and the second cycle. The researcher concluded that the application of clinical supervision of online learning during the Covid 19 pandemic for teachers at SD Negeri Krapyak, West Semarang District, Semarang City in 2020/2021 greatly influenced the improvement of teachers' pedagogic competence. The results of the supervision of the initial conditions of teacher pedagogic competence obtained an average value of $3.0(1.17 \%)$ while in the first cycle the average value of pedagogic competence was 3.5, an increase of 0.5 from the initial conditions, and in the second cycle the average value was 3.9, an increase of 0.4 from the results. previous cycle.
\end{abstract}

Keywords: Pedagogic Competence, Online learning during the covid 19 pandemic, clinical supervision

ABSTRAK: Peningkatan Kompetensi Pedagogik dalam Pembelajaran Daring Masa Pandemi Covid 19 Melalui Penerapan Supervisi Klinis pada Guru SD Negeri Krapyak Kecamatan Semarang Barat Kota Semarang Semester 2 Tahun 2020/2021. Penelitian ini bertujuan untuk mengetahui pengaruh penerapan supervisi klinis pembelajaran daring masa Pandemi Covid 19 pada guru SD Negeri KRAPYAK. Penelitian ini dilakukan selama 4 Bulan Semester II tahun pelajaran 2020 / 2021 dari penyusunan Proposal sampai penulisan laporan hasil penelitian pada bulan Desember 2020 sampai dengan April 2021. Subyek penelitian adalah seluruh guru kelas SD Negeri Krapyak. Metode merupakan suatu cara untuk mempermudah cara kerja penelitian dan merupakan faktor penentu keberhasilan sebuah penelitian. Metode yang digunakan adalah penelitian tindakan sekolah dengan tindakan sebanyak dua siklus. Tiap siklus terdiri dari empat tahapan yaitu membuat perencanaan, melakukan tindakan, mengadakan pengamatan, dan melakukan refleksi. Analisa data yang digunakan dalam penelitian ini menggunakan analisis deskriptif komparatif yaitu dengan membandingkan nilai hasil tes awal, siklus pertama, dan siklus kedua. Peneliti menarik kesimpulan bahwa penerapan supervisi klinis pembelajaran daring masa pandemic Covid 19 pada guru SD Negeri Krapyak Kecamatan Semarang Barat Kota Semarang Tahun 2020 / 2021 sangat berpengaruh terhadap peningkatan kompetensi pedagogic guru. Hasil supervise kondisi awal kompetensi pedagogic guru diperoleh nilai rata - rata 3.0 (1.17\%) sedang pada siklus I diperoleh nilai rata - rata kompetensi pedagogik 3.5 naik 0.5 dari kondisi awal, dan pada siklus II diperoleh nilai rata rata adalah 3.9 naik 0.4 dari hasil siklus sebelumnya.

Kata Kunci : Kompetensi Pedagogik, Pembelajaran daring masa pandemic covid 19, supervisi klinis 


\section{PENDAHULUAN}

Komponen organik yang sangat menentukan dalam pembelajaran dan pelaku utama penyelenggara pendidikan di sekolah adalah guru. Tidak ada kualitas pembelajaran tanpa kualitas guru. Kualitas pembelajaran tidak mungkin ada tanpa kualitas kinerja guru, sehingga peningkatan kualitas pembelajaran, juga tidaklah mungkin ada tanpa peningkatan kualitas para gurunya. Sebagai sumber daya manusia yang sangat menentukan keberhasilan pembelajaran, guru memiliki hak dan kewajiban untuk melaksanakan kegiatan belajar mengajar di lembaga pendidikan sekolah (Asrofudin, 2010: 2).

Tugas-tugas profesional dari seorang guru yaitu meneruskan atau transmisi ilmu pengetahuan, keterampilan dan nilai-nilai lain yang sejenis yang belum di ketahui anak dan seharusnya diketahui oleh anak (Anonim, 2010:2). Profesi sumber daya guru perlu terus menerus tumbuh dan berkembang agar dapat melakukan fungsinya secara profesional. Akhirakhir ini guru menjadi sorotan masyarakat. Dengan adanya sertifikasi, guru diharapkan memiliki kompetensi yang lebih baik. Akan tetapi dalam kenataannya belum bisa di lihat secara keseluruhan. Masih banyak guru belum mampu bertanggung jawab ahtas sertifikasi yang didapatkan.

Kegiatan Belajar Mengajar (KBM) merupakan salah satu komponen penting yang sangat berpengaruh terhadap mutu pendidikan di Sekolah Dasar (SD). Berhasil tidaknya tujuan pendidikan banyak tergantung kepada bagaimana proses belajar mengajar dirancang dan dilaksanakan. Kegiatan Belajar Mengajar (KBM) mengandung sejumlah komponen yang antara lain tujuan, bahan pelajaran, proses pembelajaran, metode, alat dan sumber bahan serta evaluasi (Pupuh Faithurrohman, 2007: 13).

Covid 19 adalah penyakit menular yang disebabkan oleh virus corona. Penyebaran virus ini ditransmisikan melalui percikan air liur yang dihasilkan saat orang yang terinfeksi batuk, bersin, atau menghembuskan nafas. Berada di sekitar orang yang terinfeksi Covid 19 sangat beresiko tertular, sehingga interaksi antar orang harus dibatasi untuk meminimalisir penyebaran virus ini.

Hasil pengamatan peneliti menunjukan kompetensi pedagogig pembelajaran daring masa pandemic covid 19 yang dimiliki sebagian guru SD masih rendah. Hal ini terlihat dari rata-rata nilai hasil monitoring pelaksanaan proses pembelajaran daring pada guru SDN Krapyak yang hanya 3,03 nilai tersebut masih di bawah ketentuan standar minimal kompetensi pembelajaran 3,5. Kurangnya pemahaman tentang Hakikat pembelajaran daring menyebabkan guru tidak dapat mencapai kriteria minimal yang ditetapkan dalam mengajar. Kemampuan dalam merancang dengan membuat pemetaan tema, jaringan tema, silabus dan 
RPP yang sesuai dengan peraturan Menteri pada masa pandemic Covid 19 masih perlu ditingkatkan. Keterampilan dalam proses pembelajaran dan penilaiannya belum sepenuhnya menggunakan pendekatan daring.

Kondisi tersebut disebabkan kurangnya pemahaman guru dan kurangnya sosialisasi, pembimbingan dan pembinaan dari pihak-pihak yang terait yang lebih mendalam.

Berdasarkan permasalahan tersebut maka peneliti memandang penting untuk meningkatkan kompetensi pegagogig guru dalam pembelajaran daring pada masa pademi covid 19 dengan memberikan supervisi klinis. Supervisi klinis dapat memberi informasi mengenai kekurangan dan permasalahan guru dalam proses pembelajaran kemudian untuk dibenahi dan ditingkatkan kompetensinya

\section{KAJIAN TEORI}

Menurut Rienhart (1980) dalam Ali Nugroho (2006,4.3), kompetensi merupakan indikator-indikator suatu kinerja yang berhasil dalam aktifitas kehidupan. Seseorang akan dapat melakukan suatu pekerjaan dengan baik apabila memiliki kompetensi di bidang tersebut. Kompetensi seseorang dapat dibentuk dan ditingkatkan melalui pendidikan dan pelatihan.

Sudarmanto (2009:45) mengutarakan dalam tulisannya bahwa kompetensi merupakan suatu atribut untuk melekatkan sumber daya manusia yang berkualitas dan unggul. Atribut tersebut adalah kualitas yang diberikan pada orang atau benda, yang mengacu pada karakteristik tertentu yang diperlukan untuk dapat melaksanakan pekerjaan secara efektif. Atribut tersebut terdiri atas pengetahuan, keterampilan, dan keahlian atau karakteristik tertentu.

Secara rinci, ada 5 dimensi kompetensi yang harus dimiliki oleh semua individu, yaitu :

(a) Task skills, yaitu keterampilan untuk melaksanakan tugas-tugas rutin sesuai dengan standar ditempat kerja.

(b) Task management skills, yaitu keterampilan untuk mengelola serangkaian tugas yang berbeda yang muncul dalam pekerjaan.

(c) Contigency management skills, yaitu keterampilan mengambil tindakan yang cepat dan tepat bila timbul suatu masalah dalam pekerjaan.

(d) Job role environment skills, yaitu keterampilan untuk bekerja sama serta memelihara kenyamanan lingkungan kerja.

(e) Transfer skill, yaitu keterampilan untuk beradaptasi dengan lingkungan kerja baru. 
Dari berbagai pandangan tersbeut di atas dapat disimpulkan bahwa kompetensi merupakan pengeahuan, keterampilan, dan nilai-nilai dasar atau sikap yang diwujudkan dalam cara berpikir dan bertindak. Secara sederhana kompetensi adalah kecakapan atau kemampuan (Pupuh Fathurrohman $(2007,44)$.

Undang-Undang Nomor 14 Tahun 2005 tentang Guru dan Dosen, pada pasal 10 ayat (1) menyatakan bahwa "Kompetensi guru sebagaimana dimaksud dalam Pasal 8 meliputi kompetensi pedagogik, kompetensi kepribadian, kompetensi sosial, dan kompetensi profesi. Kompetensi Pedagogik adalah kemampuan pemahaman terhadap peserta didik, perancangan dan pelaksanaan pembelajaran, evaluasi hasil belajar, dan pengembangan peserta didik untuk mengaktualisasikan berbagai potensi yang dimilikinya.

Kompetensi Kepribadian adalah kemampuan personal yang mencerminkan kepribadian yang mantap, stabil, dewasa, arif dan berwibawa, menjadi teladan bagi peserta didik, dan berakhlak mulia. Kompetensi Profesional adalah penguasaan materi pembelajaran secara luas dan mendalam, yang mencakup penguasaan materi kurikulum mata pelajaran di sekolah dan substansi keilmuan yang menaungi materinya, serta penguasaan terhadap struktur dan metodologi keilmuannya. Kompetensi Sosial adalah kemampuan guru untuk berkomunikasi dan bergaul secara efektif dengan peserta didik, tenaga kependidikan, orang tua/wali peserta didik, dan masyarakat sekitar. Pada penelitian kali ini peneliti hanya berfokus pada kompetensi pedagogik dimana kompetensi ini berkaitan dengan kemampuan mengajar guru yang akan diteliti.

Kementrian Pendidikan dan Kebudayaan telah mengeluarkan Surat Edaran Nomor 15 Tahun 2020 Tentang Pedoman Penyelenggaraan Belajar Dari Rumah Dalam Masa Darurat Penyebaran Corona Virus Disease (Covid-19).

Tujuan Pelaksanaan Belajar Dari Rumah Pelaksanaan Belajar Dari Rumah (BDR) selama darurat COVID-19 bertujuan untuk: 1. memastikan pemenuhan hak peserta didik untuk mendapatkan layanan pendidikan selama darurat COVID-19; 2. melindungi warga satuan pendidikan dari dampak buruk COVID-19; 3. mencegah penyebaran dan penularan COVID-19 di satuan pendidikan; dan 4. memastikan pemenuhan dukungan psikososial bagi pendidik, peserta didik dan orang tua/wali.

Metode dan Media Pelaksanaan Belajar Dari Rumah BDR dilaksanakan dengan Pembelajaran Jarak Jauh (PJJ) yang dibagi ke dalam 2 (dua) pendekatan: 1. pembelajaran jarak jauh dalam jaringan (daring) 2. pembelajaran jarak jauh luar jaringan (luring) Dalam pelaksanaan PJJ, satuan pendidikan dapat memilih pendekatan (daring atau luring atau kombinasi keduanya) sesuai dengan ketersediaan dan kesiapan sarana dan prasarana. 1. 
Media dan Sumber Belajar Pembelajaran Jarak Jauh Daring Pembelajaran di rumah secara daring dapat menggunakan gawai (gadget) maupun laptop melalui beberapa portal dan aplikasi pembelajaran daring, 2. Media dan Sumber Belajar Pembelajaran Luring Pembelajaran di rumah secara luring dalam masa BDR dapat dilaksanakan melalui: a. televisi, contohnya Program Belajar dari Rumah melalui TVRI; b. radio; c. modul belajar mandiri dan lembar kerja; d. bahan ajar cetak; dan e. alat peraga dan media belajar dari benda dan lingkungan sekitar.

Pelaksanaan Belajar Dari Rumah oleh Kepala Satuan Pendidikan Selama masa darurat COVID-19, kepala satuan pendidikan melakukan langkah-langkah pelaksanan BDR sebagai berikut. 1. Menetapkan model pengelolaan satuan pendidikan selama BDR, diantaranya: a. bekerja dan mengajar dari rumah bagi guru dan tenaga kependidikan. b. menentukan jadwal piket apabila diperlukan. Dalam hal dilakukan piket hendaknya berkoordinasi dengan dinas pendidikan dan gugus tugas penanganan COVID-19 setempat. 2. Memastikan sistem pembelajaran yang terjangkau bagi semua peserta didik termasuk peserta didik penyandang disabilitas. 3. Membuat rencana keberlanjutan pembelajaran. Jika masa darurat COVID-19 dan kegiatan BDR diperpanjang maka perlu mengoordinir para guru untuk berkreasi dengan menggunakan bahan ajar yang terdiri dari: a. instruksi dan materi pembelajaran daring dengan menggunakan media dan sumber belajar daring. b. instruksi dan materi pembelajaran luring dengan menggunakan televisi, radio, buku, dan modul pembelajaran mandiri peserta didik. c. intruksi untuk melakukan adaptasi materi pembelajaran untuk peserta didik penyandang disabilitas. 4. Melakukan pembinaan dan pemantauan kepada guru melalui laporan pembelajaran yang dikumpulkan setiap minggu a. memastikan guru memfasilitasi pembelajaran jarak jauh baik secara daring maupun luring; b. memastikan rencana pelaksanaan pembelajaran menerapkan pembelajaran bermakna, kegiatan kecakapan hidup dan aktivitas fisik; dan c. memastikan adanya materi edukasi untuk orang tua/wali peserta didik terkait pencegahan COVID-19 dan menerapkan pola perilaku hidup bersih di rumah. 5 . Memastikan ketersediaan sarana dan prasarana yang dimiliki guru dalam memfasilitasi pembelajaran jarak jauh baik secara daring maupun luring selama darurat COVID-19. a. Ketersediaan gawai/komputer/laptop untuk fasilitas pembelajaran daring. b. Akses ke media pembelajaran daring dan luring. c. Distribusi sarana pembelajaran luring dan alat peraga ke rumah peserta didik termasuk alat peraga pendidikan bagi peserta didik penyandang disabilitas (bagi yang tidak memiliki akses ke pembelajaran daring). d. Berkoordinasi dengan dinas pendidikan, dan/atau dinas sosial, dan/atau dinas pemberdayaan perempuan dan perlindungan anak untuk pengupayaan adanya layanan dukungan psikososial bagi pendidik, 
orang tua/wali, dan peserta didik. Layanan psikososial dapat menggunakan berbagai saluran, diantaranya: 1) layanan psikososial yang disediakan oleh Gugus Tugas Nasional Percepatan Penanganan COVID-19 melalui pusat panggilan atau call center 119 extention 8; 2) layanan psikososial oleh Himpunan Psikologi Indonesia melalui http://bit.ly/bantuanpsikologi; 3) layanan psikososial oleh Perhimpunan Dokter Spesialis Kesehatan Jiwa Indonesia http://www.pdskji.org/; dan/atau 4) layanan psikososial oleh pekerja sosial, hubungi dinas sosial setempat. 6. Membuat program pengasuhan untuk mendukung orang tua/wali dalam mendampingi peserta didik belajar, minimal satu kali dalam satu minggu. Materi tentang pengasuhan dapat dilihat pada laman https://sahabatkeluarga.kemdikbud.go.id/laman/ 7. Membentuk tim siaga darurat untuk penanganan COVID-19 di satuan pendidikan, memberikan pembekalan mengenai tugas dan tanggung jawab kepada tim, dan berkoordinasi dengan dinas pendidikan dan/atau gugus tugas penanganan COVID-19 setempat dan/atau fasilitas kesehatan/rujukan penanganan COVID-19 terdekat. 8. Memberikan laporan secara berkala kepada dinas pendidikan dan/atau pos pendidikan daerah terkait: a. kondisi kesehatan warga satuan pendidikan; b. metode pembelajaran jarak jauh yang digunakan (daring/luring/kombinasi daring dan luring); c. jumlah peserta didik yang belum bisa terlayani; d. kendala pelaksanaan BDR; dan e. praktik baik dan capaian hasil belajar peserta didik.

Pelaksanaan Belajar Dari Rumah oleh Guru Guru memfasilitasi pelaksanaan PJJ secara daring, luring, mupun kombinasi keduanya sesuai kondisi dan ketersediaan sarana pembelajaran.

Pelaksanaan Belajar Dari Rumah oleh Orang Tua/Wali Peserta Didik Pendampingan PJJ baik secara daring dan luring oleh orang tua/wali terhadap peserta didik menyesuaikan kondisi, dan ketersediaan waktu dan sarana dan prasarana pembelajaran.

Supervisi klinis adalah alat untuk memastikan bahwa penyelenggaraan pembelajaran yang dilakukan oleh guru telah efektif dengan perencanaan yang sistematis, pengamatan, dan fedback (Eko Supriyanto, 2006). Sementara itu menurut Surono $(2005,7)$ supervisi klinis adalah bentuk bimbingan profesional yang diberikan kepada guru berdasarkan kebutuhannya melalui siklus yang sistematis.

Supervisi klinis sebagai proses, didasarkan pada sejumlah asumsi pokok yaitu (1) bahwa mengajar sesungguhnya adalah seperangkat kegiatan yang komplek dan unik yang memerlukan analisis secara hati-hati. (2) guru adalah figur yang bertanggung jawab pada pembelajaran dan ia adalah profesional yang kompeten yang diharapkan membantu melalui penawaran model-model pembelajaran dalam berbagai cara dan ragam pelaksanaan. (3) 
tujuan dari supervisi klinis adalah membantu guru untuk menyesuaikan pola mengajarnya. Berdasarkan hasil pengamatan penulis, banyak guru SD yang kmampuan dan kemauannya untuk menerapkan pola pembelajaran daring di kelas masih redah. Kompetensi untuk merancang, melaksanakan, dan mengevaluasi perlu ditingkatkan.

Untuk meningkatkannya dapat dilakukan dengan supervisi klinis saat guru sedang mengajar dalam kelas virtual atau daring. Menurut Eko Supriyoko (2006) peran supervisi klinis adalah untuk membantu menuju pengembangan kemampuan guru melalui refleksi atas pengalaman atas praktik pembelajaran dan menerapkan prinsip serta konsep upaya perbaikan secara mandiri. Dengan menerapkan supervisi klinis penulis dapat mengetahui kelemahan guru dalam mengajar untuk selanjutnya diberikan pemecahannya agar guru dapat memperbaiki diri dan selanjutnya dapat melaksanakan proses pembelajaran daring dengan baik dan benar.

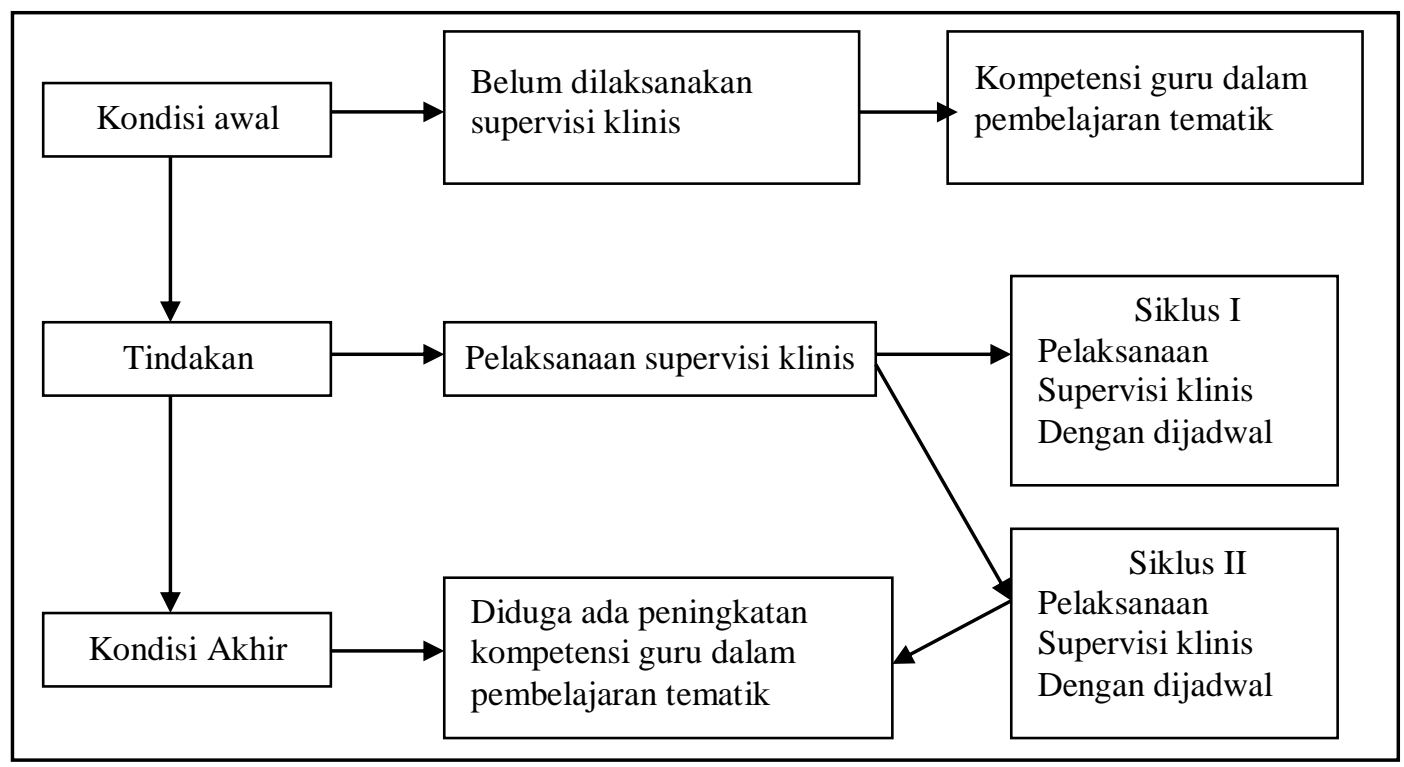

Gambar 1. Kerangka Berpikir

\section{METODE PENELITIAN}

Jenis penelitian ini adalah penelitian tindakan Sekolah (PTS). Proses penelitian berbentuk siklus berlangsung dua kali, tiap siklus 1 kali tatap muka masing-masing 70 menit (2jam pelajaran). Setiap siklus terdiri 4 kegiatan yaitu perencanaan, tindakan, observasi, dan refleksi/evaluasi. Penelitian dilakukan selama 4 bulan mulai bulan Januari sampai dengan bulan April 2021. Bulan pertama untuk membuat proposal dan menyusun instrumen penelitian. Bulan kedua pelaksanaan tindkaan dan analisa siklus I dan siklus II. Pada bulan ketiga analisis data dan pembahasan/evaluasi dan bulan keempat penyusunan laporan hasil penelitian. 
Penelitian dilakukan di SD negeri Krapyak Kecamatan Semarang Barat Kota Semarang. Peneliti mengambil sampel penelitian dua kelas yaitu kelas I dan III.Penelitian ini merupakan penelitian tindakan sekolah bedasarkan permasalahan riel tentang kemampuan guru kelas SDN Krapyak Kecamatan Semarang Barat dalam melaksanakan proses pembelajaran daring masa pandemic covid 19 yang masih rendah dan perlu ditingkatkan. Desain penelitian tindakan yang dilakukan adalah sebagai berikut :

Pada pertemuan awal dengan guru kelas I dan III diberikan penjelasan tentang Hakikat dan teknik penerapan pola pembelajaran daring. Pada siklus I dilakukan 2 kali simultan pertemuan dengan kegiatan melakukan perencanaan, pengamatan dan refleksi. Dari hasil refleksi tersebut dibuat perencanaan untuk siklus II yang dilanjutkan dengan tindakan pengamatan dan refleksi. Hasil refleksi siklus II digunakan sebagai dasar untuk menarik kesimpulan, apakah kompetensi guru dalam pembelajaran daring dapat ditingkatkan melalui supervisi klinis.

Dalam penelitian tindakan sekolah ini yang menjadi subyek adalah guru kelas I A dan III C SDN Krapyak. Peneliti sengaja hanya menggunakan 2 (dua) orang guru sebagai subyek tindakan karena mengingat terbatasnya waktu penelitian yang efektifnya kurang dari 2 (dua) bulan. Dalam penelitian ini yang menajdi obyek adalah peningkatan kompetensi pedagogic guru dalam pembelajaran daring masa pandemic covid 19.

Penelitian dilaskanakan di SDN Krapyak, Koordinator Satuan Pendidikan Kecamatan Semarang Barat. Lokasi SD tersebut termasuk dalam wilayah Kota Semarang yang sarana dan prasarananya sudah cukup memadai untuk pembelajaran daring, jumlah siswanya pun sangat banyak ada 490 anak. Sarana SD memiliki alat peraga, media dan sumber belajar relatif lengkap. Penelitian dilaksanakn selama \pm 4 bulan, dari akhir bulan Januari sampai dengan awal bulan April. Untuk sebuah penelitian tindakan waktu tersebut memang relatif sangat terbatas.

\section{HASIL PENELITIAN}

Dari hasil observasi pada Siklus I untuk guru A yang peneliti lakukan diperoleh hasil rata-rata 3,27. Agar lebih jelas hasil rata-rata tersebut peneliti sajikan kepada tabel berikut.

Tabel 1

Hasil Observasi Siklus I Pada Guru A

\begin{tabular}{|c|c|c|c|}
\hline No & Nilai & $\begin{array}{c}\text { Komponen no /Jml } \\
\text { Komponen }\end{array}$ & Jumlah Nilai \\
\hline 1 & 5 & $3(2)$ & 5 \\
\hline
\end{tabular}




\begin{tabular}{|l|l|r|c|}
\hline 2 & 4 & $2,6,9,10(4)$ & 16 \\
\hline 3 & 3 & $4,5(2)$ & 6 \\
\hline 4 & 2 & $1,7,8(3)$ & 6 \\
\hline 5 & 1 & - & 0 \\
\hline \multicolumn{2}{|c|}{ Jumlah } & 10 & 33 \\
\hline
\end{tabular}

Berdasarkan tabel diatas maka nilai rata - rata Guru A sebagai berikut :

NR $=\frac{\sum \text { nilai }}{\sum \text { komponen }}$

$\mathrm{NR}=\frac{33}{10}=3,3$

Dari data Tabel 3 tersebut dapat dianalisa bahwa perolehan nilai pada komponen 1, 4, 5, 7 dan 8 masih rendah, maka perlu ditingkatkan. Dari hasil observasi Guru B yang peneliti lakukan diperoleh hasil rata-rata 3, 5 Agar lebih jelas hasil rata-rata tersebut peneliti sajikan kepada tabel berikut.

Tabel 2

Hasil Observasi Siklus I Pada Guru B

\begin{tabular}{|c|r|r|c|}
\hline No & Nilai & \multicolumn{1}{|c|}{$\begin{array}{l}\text { Komponen no /Jml } \\
\text { Komponen }\end{array}$} & Jumlah Nilai \\
\hline 1 & 5 & $1,3,6,9(4)$ & 5 \\
\hline 2 & 4 & $4,7,8,10(4)$ & 12 \\
\hline 3 & 3 & $5(1)$ & 4 \\
\hline 4 & 2 & - & 0 \\
\hline 5 & 1 & 10 & 37 \\
\hline
\end{tabular}

Berdasarkan tabel diatas maka nilai rata - rata Guru B sebagai berikut :

NR $=\frac{\sum \text { nilai }}{\sum \text { komponen }}$

$\mathrm{NR}=\frac{37}{10}=3,5$

Berdasarkan analisa Tabel 4 dapat diketahui bahwa perolehan nilai dari Guru B pada komponen 4, 5, 7 dan 10 masih rendah, maka kompetensi guru pada komponen tersebut masih perlu ditingkatkan.

Berdasarkan tindakan pada Siklus I, untuk guru A dapat mencapai peningkatan nilai dari kondisi awal 2, 9 menjadi 3,4. Hal ini berarti ada peningkatan nilai kompetensi dalam 
pembelajaran daring dengan ukuran kuantitatif (nilai) $=0,43$. Peningkatan tersebut terutama pada komponen 3, 5 sedangkan untuk komponen 1, 4, 5, 7 dan 8 masih perlu ditingkatkan. Sementara itu untuk Guru B dapat mencapai peningkatan nilai drai kondisi awal 3,0 menjadi $3,5=0,5$ atau $1,17 \%$. Kompetensi yang meningkat adalah komponen 1, 2, 3, 8 dan 9 setingkat yang masih perlu ditingkatkan komponen 4, 5, 7, 8 dan 10 .

Dari hasil pengamatan pada siklus ini bisa dibandingkan dengan kondisi awal baik bagi Guru A maupun Guru B.

Pada observasi yang ke 2 ini peneliti menggunakan lembar pengamatan baik untuk guru A maupun guru B dengan menggunakan lembar pengamatan sama seperti pada Siklus I yaitu dengan menggunakan 11 komponen pengamatan. Dari hasil observasi pada Siklus II untuk guru A memperoleh nilai rata-rata 3,7. Agar lebih jelas hasil rata-rata tersebut peneliti sajikan kepada tabel berikut :

Tabel 3

Hasil Observasi Siklus II Pada Guru A

\begin{tabular}{|l|l|c|c|}
\hline o & Nilai & $\begin{array}{c}\text { Komponen no /Jml } \\
\text { Komponen }\end{array}$ & Numlah \\
\hline & 5 & $2,3(2)$ & 10 \\
\hline & 4 & $4,6,9,10(4)$ & 16 \\
\hline & 3 & $1,5,7(3)$ & 9 \\
\hline & $8(1)$ & 0 \\
\hline & 1 & - & 37 \\
\hline & Jumlah & 10 & \\
\hline
\end{tabular}

Berdasarkan tabel diatas maka nilai rata - rata Guru A sebagai berikut :

NR $=\frac{\text { nnilai }}{\sum \text { komponen }}$

$\mathrm{NR}=\frac{37}{10}=3,7$

Dari analisa data tersebut ternyata kemampuan mengaitkan antara materi baru dengan pengetahuan yang dimiliki siswa masih perlu ditingkatkan. Dari hasil observasi Guru B yang peneliti lakukan diperoleh hasil rata-rata 3,9. Agar jelas hasil rata-rata tersebut peneliti sajikan kepada tabel berikut :

Tabel 4

Hasil Observasi Siklus II Pada Guru B

\begin{tabular}{|l|l|l|l|}
\hline & Nilai & Komponen no /Jml & Jumlah \\
\hline
\end{tabular}




\begin{tabular}{|l|c|c|c|}
\hline o & & Komponen & Nilai \\
\hline & 5 & $2,3,4,5(4)$ & 20 \\
\hline & 4 & $9,10(2)$ & 8 \\
\hline & 3 & $1,6,7(3)$ & 9 \\
\hline & 2 & $8(1)$ & 2 \\
\hline & 1 & - & 0 \\
\hline & Jumlah & 10 & 39 \\
\hline
\end{tabular}

Berdasarkan tabel diatas maka nilai rata - rata Guru B sebagai berikut :

NR $=\frac{\sum \text { nilai }}{\sum \text { komponen }}$

$\mathrm{NR}=\frac{39}{10}=3.9$

Dari analisa data tersebut ternyata kemampuan mengaitkan antara materi baru dengan pengetahuan yang dimiliki siswa masih perlu ditingkatkan. Dari hasil observasi Guru B yang peneliti lakukan diperoleh hasil rata-rata 3,9. Untuk Guru B, dari rata-rata yaitu 3,9 dan Siklus I 3,5 maka dapat kenaikan 3,9 - 3,5 = 0,4 sehingga guru B juga ada kenaikan yang cukup signifikan yaitu $1,11 \%$ yang diperoleh dari :

$$
\begin{aligned}
& =\frac{\text { Nilai rata }- \text { rata Siklus II }}{\text { Nilai rata }- \text { rata Siklus I }} \times 1 \% \\
& =\frac{3,9}{3,5} \times 1 \% \\
& =1,11 \%
\end{aligned}
$$

\section{PEMBAHASAN}

Dalam pembahasan hasil pengamatan ini peneliti sajikan pada tabel di bawah ini.

Tabel 5

Hasil Refleksi Antar Siklus

\begin{tabular}{|c|l|c|c|c|c|c|c|}
\hline \multirow{2}{*}{ No } & \multirow{2}{*}{ Uraian } & \multicolumn{5}{|c|}{ Hasil Pengamatan } \\
\cline { 3 - 8 } & & \multicolumn{2}{|c|}{ Terendah } & \multicolumn{2}{c|}{ Tertinggi } & \multicolumn{2}{c|}{ Rata-rata } \\
\cline { 3 - 8 } & & Guru A & Guru B & Guru A & Guru B & Guru A & Guru B \\
\hline 1 & Kondisi awal & 2 & 2 & 4 & 4 & 2,9 & 3,0 \\
\hline 2 & Siklus I & 2 & 2 & 5 & 5 & 3,3 & 3,5 \\
\hline 3 & Siklus II & 2 & 2 & 5 & 5 & 3,7 & 3,9 \\
\hline
\end{tabular}

Hal. 144 
Dari kondisi awal, siklus I dan Siklus I dapat diperoleh hasil refleksi seperti tabel berikut ini:

Tabel 5

Hasil Refleksi Antar Siklus

\begin{tabular}{|c|l|c|c|c|c|c|c|}
\hline \multirow{2}{*}{ No } & \multirow{2}{*}{ Uraian } & \multicolumn{5}{|c|}{ Hasil Refleksinya } \\
\cline { 3 - 8 } & & \multicolumn{2}{|c|}{ Nilai Rata-rata } & \multicolumn{2}{|c|}{ Besarnya } & \multicolumn{2}{c|}{$\%$} \\
\cline { 3 - 8 } & & Guru A & Guru B & Guru A & Guru B & Guru A & Guru B \\
\hline 1 & Kondisi awal dan siklus I & $2,9-3,3$ & $3,0-3,5$ & 0,4 & 0,5 & 1,14 & 1,17 \\
\hline 2 & Siklus I dan Siklus II & $3,3-3,7$ & $3,5-3,9$ & 0,4 & 0,4 & 1,12 & 1,11 \\
\hline 3 & Kondisi awal dan siklus II & $2,9-3,7$ & $3,0-3,9$ & 0,93 & 0,9 & 1,27 & 1,30 \\
\hline
\end{tabular}

1. Hasil Penelitian

Dari pembahasan-pembahasan yang peneliti sampaikan dapat diperoleh hasil penelitian sebagai berikut :

Kondisi Awal : $\quad$ - Guru A 2,9

- Guru B 3,0

Siklus I

: $\quad$ - Guru A 3,3

- Guru B 3,5

Siklus II $\quad$ : $\quad$ - Guru A $\quad 3,7$

- Guru B 3,9

Sehingga hasil dari penelitian ada peningkatan yaitu hasil arta-rata dari kondisi awal sampai dengan hasil pada siklus II ada peningkatan sebesar 1,27\% untuk Guru A dan $1,30 \%$ untuk Guru B.

\section{SIMPULAN}

Berdasarkan temuan dan hasil dalam penelitian ini dapat ditarik kesimpulan bahwa:

Kompetensi guru dalam pembelajaran daring dapat ditingkatkan melalui supervisi klinis.

\section{SARAN}

1. Guru SD kelas awal selaku pelaksana proses pembelajaran hendaknya dapat mengadaptasi dan mengadopsi setiap ada inovasi pembelajaran khususnya pembelajaran daring. 
2. Kepala SD selaku manajer hendaknya mampu menciptakan suasana yang kondusif atau terselenggaranya proses pembelajaran daring di sekolahnya

3. Kepala SD selaku supervisi akademis hendaknya lebih mengoptimalkan perannya untuk membimbing guru dalam KBM

\section{DAFTAR PUSTAKA}

Depdikbud. 1996. Petunjuk Peningkatan Mutu Pendidikan di Sekolah Dasar. Jakarta : Dirjen Pendasmen.

. 1999. Petunjuk Pelaksanaan Kegaiatan Belajar Mengajara. Jakarta : Direjen Pendasmen.

Depdiknas. 2003. Kegiatan Belajar mengajar Yang Efektif. Jakarta : Puskur. .2006. Paket Pembelajaran KBM 4. Jakarta : Depdiknas.

Fathurahman Pupuh. \& Sutikno Sobry. 2007. Strategi Belajar Mengajar. Bandung : PT. Refika Aditama.

Supriyanto Eko. 2006. Prosedur Pelaksanaan Supervisi di Sekolah. Surakarta : UMS.

Sarono. 2006. Supervisi Monitoring dan Evaluasi Pendidikan. Semarang : BPPP Jawa Tengah.

Subroto, Hadi Trisno dkk. Pembelajaran Terpadu. Jakarta : UT 